\title{
Surface Integrity in Notches Machining
}

Jan Madl, Vitezslav Razek, Vaclav Koutny, Jindrich Kafka

Czech Technical University in Prague, Faculty of Mechanical Engineering, Department of Machining, Process Planning and Metrology, Technicka 4, 16607 Prague 6, Czech Republic

Precision machining and especially hard machining is a topic of high interest at present. Surface integrity requirements increase. Precision machining (mostly turning and milling) may substitute some abrasive operations. There are some advantages of precision machining over the abrasive machining. Abrasive machining has traditionally performed the finishing process of hardened steel. But, the availability of hard and super hard cutting tools enable the machine tools to reach surface quality of hard machining like to those obtained in grinding processes. But, precision machining is possible to apply also in machining common materials, not only hard materials. A surface is not only a geometric entity but also a layer with its own structure and properties. These properties are affected by many factors, e. g. by cutting temperatures, friction, deformations in the primary deformation zone and the surface layer of the transient (machined) surface, by cutting tool geometry, work hardening, cutting environment, etc.

Key words: surface integrity, precision machining, residual stresses, notches

\section{Acknowledgements}

Above mentioned results were created by means of national project GA CR No. 101/09/0504.

\section{References}

[1] KONIG, W., HOCHSCHUlE, T., KOMANDURI, R., SCHENECTADY, D., TONSHOFF, H.K. Machining of hard materials. Annals of the CIRP, 33 (2), 1984. pp. 417-427.

[2] NAKAYAMA, K.., ARAI, M., KANDA, T. Machining characteristics of hard materials, Annals of the CIRP, 37(1), 1988. pp.89-92.

[3] TONSHOFF, H.K., ARENDT, C., BEN ARMOR, R., Cutting of hardened steel. Annals of the CIRP, 49(2), 2000. pp.547-566.

[4] ABRAO, A.M., ASPINWALL, D.K., AND WISE, M.L.H. Tool wear, cutting forces and temperature evaluation when turning hardened bearing steel using PCBN and ceramics tool material. In Matador International Conferences, 1995. pp.209-216.

[5] KONIG, W., BERKTOLD, A., KOCK, K.F. Turning versus grinding: A comparison of surface integrity aspects and attainable accuracies. Annals of the CIRP, 42(1), 1993. pp.39-43.

[6] EL-WARDANY, T.I., KISHAWY, H.A., ELBESTAWI, M.A. Surface integrity of die material in high speed hard machining, part 2 : Microhardness variations and residual stresses. ASME J. Manuf. Sci. Eng., 122, 2000. pp.632641.

[7] LIU, C.R., BARASH, M.M. Variables governing patterns of mechanical residual stress in a machined surface. Trans. ASME, Ser. B, 104, 1982. pp.257-264.

[8] ELBESTAWI, M.A., CHEN, L., BESZE, C.E., EL-WARDANY, T.I. High speed milling of dies and moulds in their hardened state. Annals of the CIRP, 46(1), 1997. pp.57-62.

[9] BOEHNER, J., DUMITRESCU, M., ELBESTAWI, M.A., EL-WARDANY, T.I., LIENJING CHEN. Effect of Carbide Tool Grades and Cutting Edge Geometry on Tool Life During High Speed Machining of Hardened Tool Steel. In $2^{\text {nd }}$ Int. Conf. on High Spee, 1996.

[10] HOLEŠOVSKÝ, F., HRALA, M., NOVÁK, M. Ground Surface - Quality and its Loading Capacity. Manufacturing Technology. Vol. 3, 2003. pp. 26-32.

[11] SUTANTO. H., MADL, J., Precision Milling of Hardened Steel with Ceramics and Cubic Boron Nitride Cutting Tools, Manufacturing Technology, Vol. 7/3, 2005.

[12] SUTANTO. H., MADL, J., Precision Milling of Hardened Steel Using Ceramics and Cubic Boron Nitride Cutting Tools, Manufacturing Technology, Vol. 10/2, 2005.

[13] HOLESOVSKY, F., HRALA, M. Analyze of Influence of New Abrasive Materials on Ground Surface. In.: Proceedings of 7th International Conference on Flexible Technologies, Novi Sad, Yugoslavia, 2000. pp.211-212. 
[14] TONSHOFF, H.K., ARENDT, C. and BEN ARMOR, R. Cutting of Hardened Steel. Annals of the CIRP, volume 49, no. 2, 2000. pp. 547-566.

[15] KISHAWY, H.A., ELBESTAWI, M.A. Effects of Edge Preparation and Cutting Speed on Surface Integrity of Die Materials in Hard Machining. Proceeding of the ASME-IMECE, MED volume 8, 1998. pp. 269-276.

[16] THIELE, J.D., MELKOTE, S.N., PEASCOE, R.A. and WATKINS, T.R. Effect of Cutting Edge Geometry and Workpiece Hardness on Surface Residual Stresses in Finish Hard Turning of AISI 52100 Steel. Transaction of ASME, volume 122, 2000. pp. 642-649.

[17] MADL, J., JERSAK, J., HOLESOVSKY,F., KOUTNY, V. and RAZEK, V.: Jakost Obrabenych Povrchu (Quality of Machined Surface), UJEP, UTRV, 2003. p 179, ISBN 80-7044-539-4.

[18] MÁDL, J., RÁZEK V., KOUTNÝ, V., KAFKA, J. Surface Integrity in Notches Machining. Uetikon-Zurich: Trans Tech Publications, 2011. p. 176-181. ISBN 978-3-03785-297-2.

[19] CHEN, WUYI Cutting Forces and Surface Finish when Machining Medium Hardness Steel using CBN Tools. International Journal of Machine Tools \& Manufacture.. volume 40, 2000. pp. 455-466.

[20] DAVIES, M.A., CHOU, Y. and EVANS, C.J.: Tool Wear and Cutting Mechanics in Finish Hard Turning. Annals of the CIRP, volume 45, no. 1, 1996. pp. 77-82.

[21] SUTANTO, H., Precision Milling of Hardened Steel with Ceramics and Cubic Boron Nitride Cutting Tools. PhD. Thesis. CTU in Prague, Prague, 2004

[22] CHOU, Y.K., EVANS C.J. AND BARASH W.W. Experimental Investigation on Cubic Boron Nitride Turning $\mathrm{f}$ Hardened AISI 52100 Steel. Journal of Materials Processing Technology, 2003, volume 134, pp. 1-9. 